\title{
Incorporating different proportions of exotic maize germplasm into two adapted populations
}

\author{
Manoel Xavier dos Santos ${ }^{1}$, Linda Maria Pollak², Cleso Antônio Patto Pacheco ${ }^{1}$, \\ Paulo Evaristo Oliveira Guimarães ${ }^{1}$, Luiz Alexandre Peternelli ${ }^{3}$, Sidney Netto Parentoni ${ }^{1}$ and Luciano Lourenço Nass ${ }^{4}$
}

\begin{abstract}
Maize breeders frequently wish to use exotic germplasm in their breeding programs without losing specific characteristics of their adapted material. The objective of this study was to determine the optimal proportions of exotic germplasm to incorporate into adapted populations $\left(\mathrm{F}_{2}=50 \%\right.$ exotic, $\mathrm{BC}_{1}=25 \%$ exotic, $\mathrm{BC}_{2}=12.5 \%$ exotic and $\mathrm{BC}_{3}=6.25 \%$ exotic $)$ to form the initial foundation population and to determine the heterosis between adapted x exotics. We used six exotic populations of different origins and two adapted populations representing a Brazilian heterotic pattern. In 1993-94 and 1994-95, the parents, $\mathrm{F}_{1}, \mathrm{~F}_{2}, \mathrm{BC}_{1}, \mathrm{BC}_{2}, \mathrm{BC}_{3}$ and four checks were evaluated in six environments in central Brazil using an $8 \times 9$ simple rectangular lattice design. Higher mean values for yield were obtained as the proportion of exotic germplasm decreased. Some backcrosses produced more than the adapted populations BR 105 (7.59 ton/ha) and BR 106 (8.43 ton/ha). The best results were obtained when incorporating 6.25 or $12.5 \%$ of exotic genes. This trend was true for root lodging, stalk lodging and ear diseases but not for plant and ear height. The midparent heterosis for yield varied from - 16.1 to $40.3 \%$. Midparent heterosis with positive and negative values were also found for the other traits. The results indicate the potential of exotic germplasm for developing good hybrids. After choosing the best exotic source, some recurrent selection might be appropriate in order to adapt and improve the exotic populations.
\end{abstract}

\section{INTRODUCTION}

The importance and potential of exotic germplasm in maize has long been emphasized (Wellhausen, 1965; Brown and Goodman, 1977; Hallauer, 1978; Duvick, 1984; Holley and Goodman, 1988; Pollak, 1993; Holland and Goodman, 1995). Many maize breeders have tried to incorporate exotic germplasm into adapted cultivars to increase genetic variability and to improve the derived populations for disease and pest resistance or yield. For the most part, these efforts have failed because the amount of exotic germplasm in current use is still very small (Goodman, 1985). In Brazil, there are two major reasons for not using exotic germplasm: i) exotic germplasm is not adapted (Miranda Filho, 1992) and ii) little information is available on the agronomic value of this exotic germplasm (Nass et al., 1993), although some attempts have been made to increase the information available on useful germplasm for breeding programs (Salhuana et al., 1991; Salhuana and Sevilla, 1995).

Despite the problems and difficulties in incorporating exotic germplasm, several attempts have been made. Most results relate to the usefulness of crosses between exotic x adapted germplasm (Eberhart, 1971; Gerrish, 1983; Oyervides-Garcia et al., 1985; Holland and Goodman, 1995), the estimates of genetic parameters (Good- man, 1965; Hallauer and Sears, 1972; Sheata and Dhawan, 1975; Santos and Miranda Filho, 1992), and the determination of heterotic patterns (Holley and Goodman, 1988; Mungoma and Pollak, 1988; Pollak et al., 1991; Godshalk and Kauffmann, 1995; Uhr and Goodman, 1995; Eschandi and Hallauer, 1996).

Few studies have examined the optimal proportion of exotic germplasm that should be incorporated into adapted populations to form the initial foundation population. However, theoretical studies have indicated that the optimum generation to be used as the foundation population is a function of the genetic diversity of the parents. When the parents become more divergent, additional generations of backcrossing are advisable before beginning selection (Dudley, 1982; Crossa, 1989). When short- or long-term breeding objectives are defined and means of populations are considered, use of the $\mathrm{F}_{2}$ is advisable (Bridges and Gardner, 1987). In situations in which the mean of the adapted population is greater than that of the mean of the exotic population, the $\mathrm{BC} 1$ provides a better foundation generation.

Evaluations using adapted maize by exotic maize populations with different proportions of exotic germplasm are rare. Results with $\mathrm{F}_{2}\left(50 \%\right.$ exotic) and $\mathrm{BC}_{1}(25 \%$ exotic) indicate that the most favorable foundation population is $\mathrm{BC}_{1}$ (Albrecht and Dudley, 1987; Crossa and Gardner, 1987). 
Michelini and Hallauer (1993), working with seven exotic maize populations and three levels of introgression (75\% exotic, $50 \%$ exotic, and $25 \%$ exotic), found that the best yields were obtained for crosses with $50 \%$ exotic germplasm.

Our objectives in this study were i) to determine the optimum proportion of tropical exotic maize germplasm $\left(50 \%=\mathrm{F}_{2}, 25 \%=\mathrm{BC}_{1}, 12.5 \%=\mathrm{BC}_{2}\right.$ and $\left.6.25 \%=\mathrm{BC}_{3}\right)$ that could be introgressed into adapted populations and ii) to determine the heterosis among six tropical maize accessions and two adapted populations.

\section{MATERIAL AND METHODS}

The material used in this study were two adapted maize populations (BR 105 and BR 106) and six exotic germplasm sources (Acre 081 (AC), Amarillo 8 hileras (AO), Bolivia I-Moroti Precoce (BO), Colorado Pergamino (CP), Cravo RG (CR), and Zapalote Chico (ZC)). $\mathrm{BR} 105$ is an orange flint grain type that was introduced into Brazil from Mexico (CIMMYT). This population originally was developed from a composite formed in Thailand (Suwan) that included Caribbean germplasm. After its introduction into Brazil, it became known as BR 105 (Moro et al., 1981). BR 106 is a population formed by crosses among the Brazilian varieties Dentado Composto, Centralmex and Maya, along with Tuxpeño Planta Baja from Mexico (CIMMYT). This population represents germplasm from the Tuxpeño race with a yellow dent grain type (Santos et al., 1994). Both populations were improved by different recurrent selection schemes, and there are commercial varieties in Brazil that represent the commonly used heterotic group. The six exotic germplasms are adapted to the tropics. AO and CP are introductions from Argentina with some previous breeding in Argentina. These populations are early orange grain types. ZC was introduced from Mexico and has low plant height with white dent grain. $\mathrm{CR}$ is an accession collected in southern Brazil that shows an elevated row number (22-24). AC and BO are maize accessions collected in the Amazonian region. AC has late maturity, floury endosperm, dark brown grain and long ears $(25 \mathrm{~cm})$. BO has early maturity, floury endosperm and grain with variegated colors. All the collected accessions were cultivated by native populations and were never introduced in breeding programs (Paterniani and Goodman, 1977).

In 1987, each of the six exotic germplasm sources was crossed in Sete Lagoas, MG, to BR 105 and BR 106. To achieve flowering synchronism the exotics were planted on three dates whereas the adapted were planted on two dates. Crosses were handmade to obtain the $F_{1}$. In 1988, each $F_{1}$ was planted in an isolation block, a minimum of 60 ears was harvested, and the $\mathrm{F}_{2}$ seeds were bulked. During 1989, 1990 and 1991, the backcrosses to the adapted parents were made, and yielded $\mathrm{BC}_{1}, \mathrm{BC}_{2}$, and $\mathrm{BC}_{3}$. Each year, more than 200 plants were hand-crossed, but only 100 ears were randomly harvested. All seeds were stored in a cold room at $10^{\circ} \mathrm{C}$ and $45 \%$ relative humidity. In 1992, the parents, $\mathrm{F}_{2}$, $\mathrm{BC}_{1}, \mathrm{BC}_{2}$ and $\mathrm{BC}_{3}$ were planted and for each, 200 plants were crossed with a pollen bulk from 50 tassels. When the grain moisture was less than $15 \mathrm{~g} / \mathrm{kg}, 100$ random ears were harvested, shelled and stored after grain moisture reached $13 \mathrm{~g} / \mathrm{kg}$. This procedure produced experimental seeds of the same after one intermating generation.

The parents, $\mathrm{F}_{1}, \mathrm{~F}_{2}, \mathrm{BC}_{1}, \mathrm{BC}_{2}, \mathrm{BC}_{3}$ and four checks were evaluated during two agricultural years (1993/94 and 1994/95) at three locations: Sete Lagoas, MG (latitude $19^{\circ} 28^{\prime}$ S; longitude $44^{\circ} 15^{\prime} \mathrm{W}$; 732 masl), Goiânia, GO (latitude $17^{\circ} 28^{\prime} \mathrm{S}$; longitude $49^{\circ} 13^{\prime} \mathrm{W}$; 823 masl) and Londrina, PR (latitude $23^{\circ} 19^{\prime}$ S; longitude $51^{\circ} 19^{\prime}$ W; 585 masl). An $8 \times 9$ simple rectangular lattice field design with 72 treatments was used at each location. The plots were hand-planted and consisted of two 5-m rows with a plant density of 55,555 plants/ha. The row spacing was $0.90 \mathrm{~m}$ between rows. All plots were overplanted and thinned to the desired stand. All final stands were higher than $90 \%$. Standard cultural practices were followed for optimal maize production at all locations.

The data recorded included stand, plant height $(\mathrm{PH})$, ear height (EH), root lodging (RL), stalk lodging (SL) and ear mold resistance (ED). At harvest, the ear yield (YI) per plot in ton/ha was recorded. Grain moisture was calculated from a 100-g grain sample taken at harvest. The yield of all plots was adjusted to $14.5 \mathrm{~g} / \mathrm{kg}$.

Analysis of variance of the lattice design was carried out for each environment (year and location) according to Cochran and Cox (1957), but the lattice efficiences were low. A combined analysis was done based on a randomized complete block design using the adjusted means. Environments were considered as random effects and treatments were considered as fixed effects in the analysis of variance (Table I).

Table I - Mean squares for the combined analysis of variance of the adjusted means for yield (YI), plant height $(\mathrm{PH})$, ear height $(\mathrm{EH})$, root lodging (RL), stalk lodging (SL) and ear disease (ED).

\begin{tabular}{|lrccccccl|}
\hline Source & d.f & YI & PH & EH & RL & SL & ED & E (MS) $)^{* * *}$ \\
\hline Environment (E) & 5 & 632.22 & 264,762 & 177,576 & 41,500 & 18,156 & 26,494 & $\sigma^{2}+\mathrm{t}_{\mathrm{r} / \mathrm{e}}^{2}+\mathrm{rt}^{2}{ }_{\mathrm{e}}$ \\
Replication/E & 6 & 7.36 & 628 & 2,133 & 2,328 & 1,203 & 753 & $\sigma^{2}+\mathrm{t}_{\mathrm{r} / \mathrm{e}}^{2}$ \\
Treatment (T) & 71 & $1.38^{* *}$ & $3,002^{* *}$ & $1,994^{* *}$ & $978^{* *}$ & $306^{* *}$ & $621^{* *}$ & $\sigma^{2}+\mathrm{r}_{\mathrm{te}_{\mathrm{e}}}^{2}+\mathrm{rek}_{\mathrm{t}}{ }_{\mathrm{t}}$ \\
Tx E & 355 & $1.93^{* *}$ & $454^{* *}$ & 306 & $376^{*}$ & 234 & $153^{* *}$ & $\sigma^{2}+\mathrm{r}^{2}{ }_{\mathrm{te}}$ \\
Error & 426 & 1.06 & 293 & 274 & 293 & 219 & 91 & $\sigma^{2}$ \\
\hline
\end{tabular}

${ }^{* * * *}$ Significant at $\mathrm{P}<0.05$ and $\mathrm{P}<0.01$ level, respectively. ${ }^{* * *}$ Expected mean squares. 


\section{RESULTS AND DISCUSSION}

Six traits of primary importance to maize producers are YI, PH, EH, SL, RL and ED. Table I shows the analysis of variance of the means for these traits combined across environments. Significant differences were found among treatments for all traits. These differences were expected because the treatments represented populations with different proportions of exotic genes and the exotic genes were from different exotic sources. Treatment $x$ environment interaction mean square was highly significant $(\mathrm{P}<$ 0.01 ) for YI, PH and ED. For RL, the treatment $x$ environment interaction was significant $(\mathrm{P}<0.05)$ but no significant difference was found for EH and SL.

The highly significant interactions observed for treatment $\mathrm{x}$ environment interaction mean squares are very common in the tropics because of the large climatic variation among environments and within locations in different years, as described by Santos et al. (1994). This emphasizes that there may be a need to select a specific foundation for a specific region. For traits for which there is less environmental effect (EH and SL), it will be easier and cheaper to make selections based on experimental trials carried out in one region (Santos et al., 1994).

Mean values for the crosses between exotic and adapted for the six traits are shown in Table II. Lower YI were obtained with exotic germplasm, indicating a lack of adaptation to the environment and the useful genes were present at low frequencies. Similar results were obtained by Santos and Miranda Filho (1992) and Miranda Filho (1992) with tropical exotic germplasm and temperate maize populations, respectively. The reverse situation occurred with the adapted populations which showed greater YI, indicating a higher concentration of favorable alleles. BR 105 and BR 106 produced 7.59 ton/ha and 8.43 ton/ ha, respectively. There were also good mean values from introgression, such as $\mathrm{BC}_{2}$ of $\mathrm{BR} 105 \times \mathrm{AC}(8.75$ ton/ha) and $\mathrm{BC}_{3}$ of $\mathrm{BR} 106 \times \mathrm{CR}$ (8.80 ton/ha), among others. These yields were similar or even superior to the checks that are varieties in breeding programs or commercial double-crossed hybrids (BR 201). Frequently, the yield results with exotic germplasm were disappointing, but pa-

Table II - Means for yield (YI), plant height (PH), ear height (EH), root lodging (RL), stalk lodging (SL) and ear disease (ED) for crosses between adapted and exotic maize populations.

\begin{tabular}{|c|c|c|c|c|c|c|c|}
\hline Crosses & $\begin{array}{c}\text { Exotic } \\
(\%)\end{array}$ & $\begin{array}{c}\mathrm{YI} \\
\text { (ton/ha) }\end{array}$ & $\begin{array}{c}\mathrm{PH} \\
(\mathrm{cm})\end{array}$ & $\begin{array}{l}\mathrm{EH} \\
(\mathrm{cm})\end{array}$ & $\begin{array}{l}\mathrm{RL} \\
(\%)\end{array}$ & $\begin{array}{l}\text { SL } \\
(\%)\end{array}$ & $\begin{array}{l}\mathrm{ED} \\
(\%)\end{array}$ \\
\hline \multirow[t]{7}{*}{ BR $105 \times$ Acre 081} & 100 & 1.63 & 219 & 144 & 36.58 & 27.98 & 22.94 \\
\hline & 50 & 5.20 & 256 & 149 & 17.88 & 17.77 & 17.46 \\
\hline & 25 & 6.73 & 224 & 137 & 15.55 & 22.20 & 22.74 \\
\hline & 12.5 & 8.75 & 252 & 155 & 14.77 & 20.46 & 12.85 \\
\hline & 6.25 & 8.06 & 246 & 151 & 12.08 & 24.25 & 17.27 \\
\hline & 0 & 7.59 & 224 & 127 & 8.13 & 18.07 & 15.58 \\
\hline & $\mathrm{F}_{1}$ & 6.92 & 240 & 143 & 20.34 & 18.38 & 15.85 \\
\hline \multirow[t]{7}{*}{ BR $105 \times$ Amarillo 8 hileras } & 100 & 5.26 & 214 & 114 & 26.51 & 24.54 & 31.79 \\
\hline & 50 & 4.95 & 212 & 116 & 22.98 & 22.02 & 30.38 \\
\hline & 25 & 6.38 & 218 & 129 & 19.40 & 21.52 & 27.00 \\
\hline & 12.5 & 7.40 & 235 & 141 & 13.71 & 21.44 & 18.56 \\
\hline & 6.25 & 7.97 & 235 & 143 & 14.46 & 20.35 & 17.43 \\
\hline & 0 & 7.59 & 224 & 127 & 8.13 & 18.07 & 15.58 \\
\hline & $\mathrm{F}_{1}$ & 5.75 & 222 & 122 & 23.94 & 21.86 & 35.32 \\
\hline \multirow[t]{7}{*}{ BR 105 x Bolivia I-Moroti Precoce } & 100 & 2.33 & 197 & 109 & 54.35 & 24.93 & 30.49 \\
\hline & 50 & 5.34 & 221 & 126 & 30.91 & 21.60 & 22.11 \\
\hline & 25 & 7.16 & 235 & 139 & 18.62 & 20.63 & 16.40 \\
\hline & 12.5 & 8.12 & 12.42 & 151 & 25.27 & 18.01 & 20.05 \\
\hline & 6.25 & 8.11 & 240 & 147 & 8.70 & 22.84 & 13.80 \\
\hline & 0 & 7.59 & 224 & 127 & 8.13 & 18.07 & 15.58 \\
\hline & $\mathrm{F}_{1}$ & 6.30 & 232 & 136 & 30.20 & 25.57 & 16.01 \\
\hline \multirow[t]{7}{*}{ BR 105 x Colorado Pergamino } & 100 & 3.44 & 191 & 110 & 33.14 & 39.06 & 53.97 \\
\hline & 50 & 7.58 & 224 & 127 & 8.13 & 18.07 & 15.58 \\
\hline & 25 & 7.14 & 236 & 137 & 13.08 & 22.37 & 21.52 \\
\hline & 12.5 & 7.85 & 247 & 147 & 17.35 & 20.96 & 19.02 \\
\hline & 6.25 & 7.86 & 243 & 149 & 10.04 & 25.20 & 16.17 \\
\hline & 0 & 7.59 & 224 & 127 & 8.13 & 18.07 & 15.58 \\
\hline & $\mathrm{F}_{1}$ & 6.30 & 216 & 121 & 23.57 & 23.29 & 26.95 \\
\hline \multirow[t]{4}{*}{ BR 105 x Cravo RG } & 100 & 3.82 & 232 & 152 & 49.15 & 20.58 & 33.59 \\
\hline & 50 & 7.06 & 241 & 145 & 28.60 & 12.62 & 19.53 \\
\hline & 25 & 7.90 & 248 & 155 & 18.72 & 20.75 & 17.72 \\
\hline & 12.5 & 8.44 & 242 & 155 & 16.04 & 29.03 & 22.40 \\
\hline
\end{tabular}


Table II - Continued

\begin{tabular}{|c|c|c|c|c|c|c|c|}
\hline Crosses & $\begin{array}{c}\text { Exotic } \\
(\%)\end{array}$ & $\begin{array}{c}\mathrm{YI} \\
\text { (ton/ha) }\end{array}$ & $\begin{array}{l}\mathrm{PH} \\
(\mathrm{cm})\end{array}$ & $\begin{array}{l}\mathrm{EH} \\
(\mathrm{cm})\end{array}$ & $\begin{array}{l}\mathrm{RL} \\
(\%)\end{array}$ & $\begin{array}{l}\text { SL } \\
(\%)\end{array}$ & $\begin{array}{l}\mathrm{ED} \\
(\%)\end{array}$ \\
\hline \multirow[t]{3}{*}{ BR 105 x Cravo RG } & 6.25 & 7.59 & 241 & 152 & 14.18 & 20.34 & 17.30 \\
\hline & 0 & 7.59 & 224 & 127 & 8.13 & 18.07 & 15.58 \\
\hline & $\mathrm{F}_{1}$ & 7.96 & 248 & 157 & 21.26 & 18.61 & 15.83 \\
\hline \multirow[t]{7}{*}{ BR 105 x Zapalote Chico } & 100 & 1.48 & 160 & 96 & 48.39 & 29.97 & 44.72 \\
\hline & 50 & 4.37 & 196 & 116 & 18.83 & 18.70 & 22.65 \\
\hline & 25 & 6.42 & 218 & 135 & 17.94 & 18.50 & 16.77 \\
\hline & 12.5 & 7.43 & 232 & 145 & 14.94 & 23.66 & 16.63 \\
\hline & 6.25 & 8.38 & 240 & 145 & 8.55 & 18.49 & 16.12 \\
\hline & 0 & 7.59 & 224 & 127 & 8.13 & 18.07 & 15.58 \\
\hline & $\mathrm{F}_{1}$ & 5.01 & 209 & 121 & 30.81 & 21.89 & 12.42 \\
\hline \multirow[t]{7}{*}{ BR 106 x Acre 081} & 100 & 1.63 & 219 & 145 & 36.58 & 27.98 & 22.94 \\
\hline & 50 & 4.53 & 245 & 148 & 26.29 & 17.08 & 24.42 \\
\hline & 25 & 6.98 & 240 & 137 & 21.30 & 13.91 & 16.29 \\
\hline & 12.5 & 6.84 & 246 & 146 & 23.50 & 18.28 & 18.13 \\
\hline & 6.25 & 6.98 & 242 & 143 & 20.13 & 17.29 & 18.06 \\
\hline & 0 & 8.43 & 2.36 & 1.38 & 19.45 & 13.49 & 12.19 \\
\hline & $\mathrm{F}_{1}$ & 5.50 & 245 & 154 & 32.51 & 16.97 & 15.72 \\
\hline \multirow[t]{7}{*}{ BR 106 x Amarillo 8 hileras } & 100 & 5.26 & 214 & 114 & 26.51 & 24.54 & 31.79 \\
\hline & 50 & 4.50 & 217 & 118 & 26.07 & 31.80 & 28.15 \\
\hline & 25 & 6.46 & 231 & 134 & 35.65 & 14.85 & 23.98 \\
\hline & 12.5 & 6.25 & 224 & 126 & 32.31 & 14.29 & 24.25 \\
\hline & 6.25 & 6.64 & 240 & 132 & 25.41 & 12.94 & 20.43 \\
\hline & 0 & 8.04 & 236 & 138 & 19.45 & 13.49 & 12.19 \\
\hline & $\mathrm{F}_{1}$ & 5.73 & 222 & 120 & 36.09 & 26.07 & 21.44 \\
\hline \multirow[t]{7}{*}{ BR106 x Bolivia I-Moroti Precoce } & 100 & 2.33 & 197 & 109 & 54.35 & 24.93 & 30.49 \\
\hline & 50 & 5.26 & 234 & 140 & 28.36 & 26.14 & 20.26 \\
\hline & 25 & 7.18 & 235 & 137 & 24.30 & 19.25 & 17.66 \\
\hline & 12.5 & 7.13 & 232 & 139 & 29.05 & 23.34 & 12.78 \\
\hline & 6.25 & 7.32 & 242 & 134 & 22.54 & 15.37 & 14.36 \\
\hline & 0 & 8.43 & 236 & 138 & 19.45 & 13.49 & 12.19 \\
\hline & $\mathrm{F}_{1}$ & 5.90 & 236 & 125 & 27.65 & 22.12 & 19.42 \\
\hline \multirow[t]{7}{*}{ BR106 x Colorado Pergamino } & 100 & 3.44 & 191 & 110 & 33.14 & 39.06 & 53.97 \\
\hline & 50 & 6.37 & 217 & 124 & 30.93 & 20.17 & 24.85 \\
\hline & 25 & 7.25 & 224 & 138 & 16.32 & 27.15 & 19.69 \\
\hline & 12.5 & 7.64 & 239 & 145 & 16.88 & 16.27 & 13.74 \\
\hline & 6.25 & 8.02 & 244 & 148 & 19.27 & 17.00 & 16.45 \\
\hline & 0 & 8.43 & 236 & 138 & 19.45 & 13.49 & 12.19 \\
\hline & $\mathrm{F}_{1}$ & 6.70 & 214 & 120 & 21.14 & 27.18 & 21.77 \\
\hline \multirow[t]{7}{*}{ BR 106 x Cravo RG } & 100 & 3.82 & 232 & 152 & 49.15 & 20.85 & 33.59 \\
\hline & 50 & 6.37 & 241 & 148 & 23.21 & 20.81 & 16.04 \\
\hline & 25 & 8.14 & 239 & 142 & 23.95 & 17.21 & 15.17 \\
\hline & 12.5 & 7.55 & 243 & 146 & 22.25 & 14.03 & 18.30 \\
\hline & 6.25 & 8.80 & 245 & 148 & 15.24 & 12.58 & 15.07 \\
\hline & 0 & 8.43 & 236 & 138 & 19.45 & 13.49 & 12.19 \\
\hline & $\mathrm{F}_{1}$ & 7.27 & 247 & 155 & 29.87 & 14.24 & 14.48 \\
\hline \multirow[t]{7}{*}{ BR 106 x Zapalote Chico } & 100 & 1.48 & 160 & 96 & 48.39 & 29.97 & 44.72 \\
\hline & 50 & 4.25 & 218 & 131 & 28.56 & 28.75 & 17.23 \\
\hline & 25 & 6.43 & 234 & 136 & 24.44 & 19.81 & 17.91 \\
\hline & 12.5 & 6.92 & 237 & 136 & 22.63 & 14.10 & 19.18 \\
\hline & 6.25 & 7.68 & 234 & 140 & 20.81 & 15.14 & 16.23 \\
\hline & 0 & 8.43 & 236 & 138 & 19.45 & 13.49 & 12.19 \\
\hline & $\mathrm{F}_{1}$ & 5.75 & 213 & 129 & 28.75 & 26.10 & 13.77 \\
\hline \multicolumn{8}{|l|}{ Checks } \\
\hline Sintetico Elite & & 7.48 & 237 & 131 & 20.15 & 21.49 & 18.28 \\
\hline CMS 50 & & 8.45 & 245 & 146 & 12.20 & 13.38 & 16.35 \\
\hline BR 201 & & 7.98 & 236 & 138 & 30.60 & 19.46 & 12.72 \\
\hline CMS 39 & & 9.12 & 243 & 145 & 20.09 & 16.17 & 17.68 \\
\hline $\operatorname{LSD}(0.05)$ & & 1.11 & 17 & 14 & 15.58 & 12.27 & 9.94 \\
\hline CV\% & & 14.9 & 6.5 & 9.0 & 58.29 & 51.94 & 43.42 \\
\hline
\end{tabular}


tience and persistence are fundamental when working with exotic germplasm (Geadelmann, 1984); a good choice of exotic germplasm is also crucial (Goodman, 1985).

Greater mean values for YI were obtained as the proportion of exotic germplasm decreased. This trend was observed in all crosses although in some situations no significant difference was detected among treatments. Backcrossing to the adapted parents increased the mean and overcame the lack of adaptability of exotic germplasm. Comparing the crosses between exotics and adapted populations of BR 105 and BR 106, crosses with BR 105 gave the greatest YI.

Very little work has been done to determine the best proportion of exotic genes to be integrated into adapted populations, and in that which what has been done, introgressed populations with less than $25 \%$ exotic genes were not used. Investigations with adapted cultivars and exotic germplasm that had undergone some selection for adaptation found that $\mathrm{BC}_{1}$ was the best foundation population (Albrecht and Dudley, 1987; Crossa and Gardner, 1987), but suggested additional backcrosses to improve the mean yield. Theoretical studies and computer simulations have supported these results, showing that the ideal proportion of unadapted germplasm used in a foundation population decreases as the divergence between the two parents increases (Dudley, 1982; Bridges and Gardner, 1987; Crossa, 1989). However, different results were reported by Michelini and Hallauer (1993), who found higher mean yields when $50 \%$ of the genes were from exotic germplasms.

The results of this study may be questioned because the populations with different proportions of exotic genes were not sufficiently randomly intermated to disrupt gene combinations (Nelson, 1973; Lonnquist, 1975). However, the results of Hoffbeck et al. (1995) support our findings, because these authors worked with three backcross levels and randomly intermated for five generations. They found that the effect on intermating on grain yield was not significant, despite the higher mean yield and reduced genetic variance, because the backcrossed populations shifted the gene frequencies. Independently of the origin and production potential of each tropical exotic population, we conclude that backcrosses increased the mean YI mean and the best foundation populations were obtained by incorporating $6.25 \%\left(\mathrm{BC}_{3}\right)$ or $12.5 \%\left(\mathrm{BC}_{2}\right)$ exotic genes into adapted populations.

Estimates of midparent heterosis for the six traits are summarized in Table III. For YI, BR 105, when crossed with exotic populations, showed higher values for heterosis than BR 106. The highest midparent heterosis values for YI were in crosses of BR 105 with the exotics CR (40.3\%) and BO (28.6\%). BR $106 \times$ CR and BR $106 \times$ ZC were 19.7 and $16.3 \%$, respectively. Negative midparent heterosis values were found for the exotic AO with both adapted parents. Similar results were reported by Santos (1995), who showed that midparent heterosis values for tropical accessions from Latin America in crosses with BR 105 varied from -28 to $26 \%$ and from -33 to $17 \%$ in crosses with BR 106. Michelini and Hallauer (1993) showed a midparent heterosis of $89.6 \%$ with Suwan-1 (BR $105)$ in the Corn Belt when crossed with the improved BS13(S)C4 derived from BSSS. BR 105 is primarily Caribbean germplasm that has been exploited in Brazil as one half of the common heterotic pattern with BR 106 (Tuxpeño), but there are results showing the potential of Suwan as a Corn Belt heterotic group (Goodman, 1985; Pollak et al., 1991).

Crosses of exotic populations with BR 105 and BR 106 showed a general trend for positive heterosis for the traits $\mathrm{PH}$ and $\mathrm{EH}$. Exceptions were found for the exotic $\mathrm{AO}$ with both adapted parents and for $\mathrm{EH}$ in the exotic $\mathrm{CP}$ crossed with BR 106. Similar trends were observed by Michelini and Hallauer (1993) for heterosis of ear height.

The percentage of heterosis for RL increased above the midparent in crosses of $\mathrm{AO}, \mathrm{CP}$ and ZC with BR 105 and in the cross $\mathrm{AC}$ and $\mathrm{AO}$ with BR 106. For SL, the crosses between BR 105 and BO and between BR 106 and AO showed higher positive heterosis (28.2 and $37.1 \%$, respectively). For both traits, the exotic $\mathrm{AO}$ was unique in showing positive heterosis with the adapted parents whereas with the exotic CR, the reverse was true. By comparing the mean results obtained among exotic germplasm in crosses with the adapted parents, BR 105 was found to decrease SL whereas BR 106 reduced RL. Considering that tropical germplasm exhibits weak roots and stalks (Santos, 1995), we consider these results promising.

Table III - Midparent heterosis (\%) for six traits from crosses of tropical adapted maize populations x exotic germplasms.

\begin{tabular}{|c|c|c|c|c|c|c|c|c|c|c|c|c|}
\hline \multirow{2}{*}{$\begin{array}{l}\text { Exotic } \\
\text { populations }\end{array}$} & \multicolumn{2}{|c|}{ Yield } & \multicolumn{2}{|c|}{ Plant height } & \multicolumn{2}{|c|}{ Ear height } & \multicolumn{2}{|c|}{ Root lodging } & \multicolumn{2}{|c|}{ Stalk lodging } & \multicolumn{2}{|c|}{ Ear disease } \\
\hline & BR 105 & BR 106 & BR 105 & BR 106 & BR 105 & BR 106 & BR 105 & BR 106 & BR 105 & BR 106 & BR 105 & BR 106 \\
\hline Acre 081 & 5.0 & 11.1 & 8.3 & 7.7 & 5.5 & 8.8 & -9.0 & 16.1 & -20.0 & -18.1 & -17.7 & -10.5 \\
\hline Amarillo 8 hileras & -10.0 & -16.1 & 1.4 & -1.3 & 1.2 & -4.7 & 38.2 & 57.0 & 2.6 & 37.1 & 49.1 & -2.5 \\
\hline Bolivia I-Moroti Precoce & 28.6 & 11.3 & 10.2 & 9.0 & 15.2 & 1.2 & -3.3 & -25.0 & 28.2 & -15.1 & -30.5 & -9.0 \\
\hline Colorado Pergamino & 14.5 & 13.5 & 4.0 & 0.2 & 2.1 & -3.2 & 14.2 & -19.6 & -18.4 & 3.4 & -22.5 & -34.0 \\
\hline Cravo RG & 40.3 & 19.7 & 8.7 & 5.5 & 12.5 & 6.9 & -25.8 & -12.9 & -3.7 & -17.6 & -35.6 & -37.0 \\
\hline Zapalote Chico & 11.1 & 16.3 & 8.8 & 7.5 & 8.5 & 10.2 & 9.0 & -15.2 & -8.8 & 20.1 & -58.8 & -51.6 \\
\hline Mean & 14.9 & 9.3 & 6.9 & 4.7 & 7.5 & 3.2 & 3.9 & 0.1 & -3.3 & 1.6 & -19.3 & -24.1 \\
\hline
\end{tabular}


For ED, the superiority of the adapted population over the exotics was seen through the negative heterosis in all crosses except AO. The highest midparent heterosis values were observed in the crosses of the exotic $\mathrm{ZC}$ with BR $105(-58.8 \%)$ and ZC with BR $106(-51.6 \%)$. In all crosses, the $\mathrm{F}_{1}$ mean $\mathrm{ED}$ (ear mold) incidence was less than or equal to that of the adapted parents (Table II). The lower incidence of disease in the adapted populations was a result of the recurrent selection schemes that have been carried out over the years (Santos et al., 1994).

The heterotic responses seen in this study show the potential for using exotic germplasm in crosses with adapted populations. This heterosis may be exploited by maize breeders by using improvement through recurrent selection with the best exotic populations in order to get good inbred lines. Highly productive hybrids can be obtained because the presence of favorable genes in inbred lines is a function of the gene frequencies of the parents.

\section{RESUMO}

Os melhoristas de milho que utilizam germoplasmas exóticos nos programas de melhoramento têm a preocupação de não perder as características desejáveis dos materiais adaptados. Buscando atender esta demanda, o presente trabalho teve por objetivo determinar a proporção ideal de germoplasma exótico que deve ser incorporado em populações melhoradas $\left(\mathrm{F}_{2}=50 \%\right.$ exótico; $\mathrm{RC}_{1}=25 \%$ exótico; $\mathrm{RC}_{2}=12,5 \%$ exótico; $\mathrm{RC}_{3}=6,25 \%$ exótico), para formar as populações base para seleção e determinar a heterose entre os germoplasmas exóticos e adaptados. Em 1993/ 94 e 1994/95, os parentais, $F_{1}, F_{2}, R_{1}, R_{2}, R_{3}$ e quatro testemunhas foram avaliados em seis ambientes da região central do Brasil, utilizando-se o delineamento em látice simples $8 \times 9$. De um modo geral, à medida que a proporção de germoplasma exótico decresceu, valores médios mais altos foram obtidos para o caráter peso de espigas. Alguns retrocruzamentos produziram mais que as populações melhoradas BR $105(7.500 \mathrm{~kg} / \mathrm{ha})$ e BR 106 $(8.430 \mathrm{~kg} / \mathrm{ha})$. Os melhores resultados foram obtidos quando houve a incorporação de 6,25 ou 12,5\% de genes exóticos. Esta tendência foi observada para acamamento, quebramento e espigas doentes, mas não para altura de planta e de espiga. A heterose média para peso de espiga variou de $-16,1$ a $40,3 \%$. Heteroses médias com valores positivos e negativos também foram encontradas para outros caracteres. Os resultados obtidos mostraram o potencial em se utilizar germoplasmas exóticos para a obtenção de híbridos. Sugere-se, após a escolha dos germoplasma, algum esquema de seleção recorrente para adaptar e melhorar as populações exóticas.

\section{REFERENCES}

Albrecht, B. and Dudley, J.W. (1987). Evaluation of four maize populations containing different proportions of exotic germplasm. Crop Sci. 27: 480-486.

Bridges, W.C. and Gardner, C.O. (1987). Foundation populations for adapted by exotic crosses. Crop Sci. 27: 501-506.

Brown, W.L. and Goodman, M.M. (1977). Races of maize. In: Corn and Corn Improvement (Sprague G.F. and Dudley, J.W., eds.). ASA, Madison, pp. 48-88.

Cochran, W.G. and Cox, G.M. (1957). Experimental Designs. 2nd edn. John
Wiley \& Sons, Inc., New York, pp. 611.

Crossa, J. (1989). Theoretical considerations for the introgression of exotic germplasm into adapted maize populations. Maydica 34: 53-62.

Crossa, J. and Gardner, C.O. (1987). Introgression of an exotic germplasm for improving an adapted maize population. Crop Sci. 27: 187-190.

Dudley, J.W. (1982). Theory for transfer alleles. Crop Sci. 22: 631-637.

Duvick, D.N. (1984). Genetic diversity in major farm crops on the farm and in reserves. Econ. Bot. 38: 161-178.

Eberhart, S.A. (1971). Regional maize diallel with US and semi-exotic varieties. Crop Sci. 11: 911-914.

Eschandi, C.R. and Hallauer, A.R. (1996). Evaluation of U.S. corn belt and adapted tropical maize cultivars and their diallel crosses. Maydica 41: 317-324.

Geadelmann, J.L. (1984). Using exotic germplasm to improve northern corn. In: Proceedings of the 39th Annual Corn Sorghum Research Conference, Chicago, IL, 4-6 Dec. 1984 (Wilkinson, D., ed.). American Seed Trade Association, Washington, DC., pp. 98-109.

Gerrish, E.E. (1983). Interactions from a diallel study for interracial hybridization in the Corn Belt. Crop Sci. 23: 1082-1084.

Godshalk, E.B. and Kauffmann, K.D. (1995). Performance of exotic x temperate single-cross maize hybrids. Crop Sci. 35: 1042-1045.

Goodman, M.M. (1965). Estimates of genetic variance in adapted and exotic populations of maize. Crop Sci. 5: 87-90.

Goodman, M.M. (1985). Exotic maize germplasm: status and prospects. Iowa State J. Res. 59: 497-527.

Hallauer, A.R. (1978). Potential of exotic germplasm for maize improvement. In: Maize Breeding and Genetics (Walden, D.B., ed.). John Wiley \& Sons, New York, pp. 229-247.

Hallauer, A.R. and Sears, J.H. (1972). Integrating exotic germplasm into Corn Belt maize breeding programs. Crop Sci. 12: 203-206.

Hoffbeck, M.D., Openshaw, S.J., Geadelman, J.L., Peterson, R.H. and Stuthman, D.D. (1995). Backcrossing and intermating in an exotic $x$ adapted cross of maize. Crop Sci. 35: 1359-1364.

Holland, J.B. and Goodman, M.M. (1995). Combining ability of tropical maize accessions with U.S. germplasm. Crop Sci. 35: 767-773.

Holley, R.N. and Goodman, M.M. (1988). Yield potential of tropical hybrid maize derivatives. Crop Sci. 28: 213-218.

Lonnquist, J.H. (1975). Consideration and experiences with recombinations of exotic and Corn Belt maize germplasm. In: 30th Report of Annual Corn Sorghum Research Conference. Chicago, IL, 10-12 Dec. 1975 (Loden, H.D. and Wilkinson, D., eds.). American Seed Trade Association, Washington, DC, pp. 102-117.

Michelini, L.A. and Hallauer, A.R. (1993). Evaluation of an exotic and adapted maize germplasm crosses. Maydica 38: 275-282.

Miranda Filho, J.B. (1992). Exotic germplasm introduced in a Brazilian maize breeding program. Rev. Bras. Genet. 15: 631-642.

Moro, J.R., Naspolini Filho, V., Viana., R.T. and Gama, E.E.G. (1981). Introdução de novos germoplasmas de milho no Brasil. Pesqui. Agropecu. Bras. 16: 867-882.

Mungoma, C. and Pollak, L.M. (1988). Heterotic pattern among ten corn belt and exotic maize populations. Crop Sci. 28: 500-504.

Nass, L.L., Pellicano, I.J. and Valois, A.C.C. (1993). Utilization of genetic resources for maize and soybean breeding in Brazil. Rev. Bras. Genet. 16: $983-988$

Nelson, H.G. (1973). The use of exotic germplasm in practical corn breeding programs. In: Report of the 28th Annual Corn Sorghum Research Conference. Chicago, IL, 4-6 Dec. 1973 (Wilkinson, D., ed.). American Seed Trade Association, Washington, DC, pp. 115-118.

Oyervides-Garcia, M., Hallauer, A.R. and Cortez-Mendonza, H. (1985). Evaluation of improved maize populations in Mexico and the U.S. Corn Belt. Crop Sci. 25: 115-120.

Paterniani, E. and Goodman, M.M. (1977). Races of Maize in Brazil and Adjacent Areas. CIMMYT, Mexico City.

Pollak, L.M. (1993). Evaluation of Caribbean maize accessions in Puerto Rico. Trop. Agric. 70: 8-12.

Pollak, L.M., Torres Cardona, S. and Sotomayor-Rios, A. (1991). Evaluation of heterotic patterns among Caribbean and tropical-temperate maize populations. Crop Sci. 31: 1480-1483.

Salhuana, W. and Sevilla, R. (1995). Latin American Maize Project (LAMP). Stage 4 Results from Homologous Areas 1 and 5. ARS Special Publication, Beltsville. 
Salhuana, W., Jones, Q. and Sevilla, R. (1991). The Latin American Maize Project: model for rescue and use of irreplaceable germplasm. Diversity 7: 40-42.

Santos, M.X. (1995). Resultados de Lamp de la etapa 4 en Brazil. In: Latin American Maize Project (LAMP), Stage 4, Results for Homologous Area 1 and 5 (Salhuana, W. and Sevilla, R., eds.). ARS Special Publication, Beltsville, pp. 33-67.

Santos, M.X. and Miranda Filho, J.B. (1992). Genetic potential of two Brazilian races of maize for breeding purposes. J. Genet. Breed. 46: 83-90.

Santos, M.X., Pacheco, C.A.P., Guimaraes, P.E.O., Gama, E.E.G., Silva, A.E. and Oliveira, A.C. (1994). Diallel among twenty-eight varieties of maize. Rev. Bras. Genet. 17: 277-282.
Sheata, A.H. and Dhawan, N.L. (1975). Genetic analysis of grain yield in maize as manifested in diverse varietal populations and their crosses. Egypt. J. Genet. Cytol. 4: 90-116.

Uhr, D.V. and Goodman, M.M. (1995). Temperate maize inbreeds derived from tropical germplasm: I. Testcross yield trials. Crop Sci. 35: 779784.

Wellhausen, E.J. (1965). Exotic germplasm for improvement of corn belt maize. In: 20th Report of Hybrid Corn Industry-Research Conference. Chicago, IL, 8-9 Dec. 1965 (Sutherland, J.I., ed.). American Seed Trade Association, Washington, DC, pp. 31-45.

(Received September 15, 1999) 
